\title{
Strategic or Stringent? Understanding the Nationality Blindness of EU Competition Policy from the Regulatory State Perspective
}

Hikaru Yoshizawa

\section{Introduction}

Over the last six decades, the EU has gradually developed its competition policy, and it now has a considerable regulatory impact on the market to the extent that companies, both EU and non-EU, can hardly ignore the supranational competition law when conducting economic activities in the European internal market. While EU competition policy has long been a classic case study in European integration and Europeanization research, placing emphasis on intraregional political, economic and legal dynamics, the literature increasingly focuses on the international dimension of this policy. Not only lawyers and economists, but also political scientists pay close attention to the external aspects of the EU's competition regulation because it strongly affects third countries, their companies, and ultimately their consumers. The fact that the infringement of EU competition law by firms may result in penalty fees as high as hundreds of millions of euros underlines the significance of this regulatory policy for third jurisdictions. In this sense, EU competition policy exemplifies the enormous global impact of the EU's internal policies', especially in the area of economic and social regulation.

Yet, the existing literature has insufficiently addressed the question of whether the EU discriminates non-EU based companies in the competition domain for industrial policy purposes. An interesting point in this 
Strategic or Stringent? Understanding the Nationality Blindness of EU Competition Policy from the Regulatory State Perspective (Yoshizawa)

respect is that there is some evidence of the neutrality of EU competition policy in terms of the nationality of firms, despite the ever-growing importance of international competitiveness in the EU's discourse (see Section 2 below), and a wide range of policy instruments at its disposal. Successive European Commissioners for Competition have been not surprisingly denying the instrumental use of competition law for industrial policy goals. What is more important and more interesting is that even third states such as Japan and the US agree with this point, as will be presented in Section 1, although their opinion of the EU's competition regulation is generally critical as far as analytical methods and investigative procedures are concerned. How can this puzzling phenomenon be understood from a theoretical point of view?

This article argues that in order to better understand the issue of nationality-based (non-) discrimination in EU competition policy, one should explicitly link it to the wider 'competition and/versus competitiveness' debate in the study of international political economy. Specifically, in order to explain the puzzle of the nationality blindness of EU competition policy even vis-à-vis third-country based companies, the article makes a distinction between two models, 'stringent' and 'strategic' competition policies, which rest on potentially irreconcilable conceptions of competition and competitiveness in economic governance. Stringent competition policy is an original model proposed in this study and emphasizes the non-discriminatory nature of supranational competition policies such as the EU's one, in sharp contrast to an essentially neomercantilistic idea of strategic competition policy developed to some extent in the existing literature.

The model of stringent competition policy draws on the theory of the regulatory state and sociological institutionalism. This new conceptual tool is useful to understand how the supranational institutional setting and the market integration ethos of the EU have shaped its peculiar conception of competition and competitiveness underpinning its competi- 
tion policy, which centers on the maintenance of a level-playing field (competition-oriented perspective) rather than the creation of 'European champions' through the discrimination of non-EU based companies (competitiveness-oriented perspective). It should be noted that the two 'models' presented in this study are heuristic devices (or ideal types in the Weberian sense) for the better understanding of a complex reality in the competition policy domain. In other words, this research does not claim that the EU should follow one of them-it is merely the case that one is widely believed to be better than the other among policy makers. The article also takes a position that there is no 'correct' balance between the goals of competition and competitiveness, and that there is only a balance that is widely believed to be appropriate at a given time and place. This reflective approach is chosen because the research intends to empirically examine, and not to predefine, the EU's primary goal in competition regulation.

The following analysis rests on two key methodological choices. First, this research employs an inductive and yet theory-informed method of hypothesis generation. Empirical observations provide a basis for model building, whereas the theories mentioned above play a key role in developing the new model in a structured and coherent way. Second, it uses multiple sources, both EU and non-EU, in order to avoid the potential pitfalls of excessively pro- or anti-EU arguments. This methodological choice is crucial because of the nature of the subject of this research.

It should also be noted that the article focuses on the development of an analytical framework. It examines several concrete competition cases to build and illustrate the two models, but a comprehensive empirical analysis for hypothesis testing is beyond its scope. The cases used in the following sections for model building are mainly, but not exclusively, merger cases because merger regulation has been one of the most controversial areas in external competition regulation. A more systematic 
Strategic or Stringent? Understanding the Nationality Blindness of EU Competition Policy from the Regulatory State Perspective (Yoshizawa)

empirical analysis is necessary to ascertain whether the argument made in this article fits some areas of competition policy better than others.

The article proceeds in the following way. Section 1 briefly reviews major studies of EU competition policy, primarily those which are written by political scientists. It also underlines an ever-greater scholarly focus on its international dimension, and identifies a gap in the literature. Next, Section 2 reveals features of the incipient model of strategic competition policy. Then, Section 3 points out empirical and theoretical problems with this model, and in addition proposes a new model of stringent competition policy. This section also explains main differences and similarities between the two models. Based on these dialectic arguments, Section 4 summarizes major findings, explains their implications, and identifies key venues for further research.

\section{Literature on the external dimension of EU competition policy}

EU competition policy has been a classic case study in regional integration research because the former stands out among EU public policies in terms of supranational institutional setting. Incremental policy development at the supranational level, especially since the $1980 \mathrm{~s}$, has been a stimulation of this strand of research, and the same can be said about scholarly inquiries for this policy from the Europeanization perspective. Despite theoretical and methodological diversity, these two bodies of literature share a clear focus on intraregional dynamics, be they political, economic or legal.

While contemporary issues such as the modernization reform of the EU's competition regime in 2004 continue to inspire further research on the evolving nature of supranationality in this field, the center of gravity in the political science literature on this policy seems to be shifting from the internal dynamic to the external one. For example, A. S. Papadopoulos provides a comprehensive comparative study of bilateral and 
multilateral agreements between the EU and third countries, while explaining the EU's motive for external policy transfer and commitment to the international cooperation on competition. In turn, D. Gerber studies the role of the $\mathrm{EU}$ in various international institutions such as the International Competition Network, which aim for competition law convergence on a global scale. In respect of a more coercive side of this policy, M. M. Dabbah examines the development of legal doctrines that underpin the EU's extraterritorial application of competition law, whereas Y. Aoyagi analyzes internal sources and an external impact of the EU's regulatory power, providing a potential platform for dialogue between legal and political science ${ }_{9}$ studies on the international dimension of EU competition policy. U. Aydin synthesizes these strands of research by illustrating how the EU has been attempting to use its various external competition policy instruments (bilateral agreements, multilateral negotiations, extraterritoriality, and rule exportation through enlargement) in a consistent and coherent way. Altogether, these works constitute a growing literature on the $\mathrm{EU}$ as a global regulatory power in the competition policy domain.

That being said, despite such a clear interest in the international dimension, existing works tend to narrowly focus on the effectiveness and processes of the EU's external competition regulation, while inadequately addressing the issue of nationality based (non-) discrimination by EU competition regulators. This is why a conceptual tool for the analysis of this issue, which is of great importance for third jurisdictions, should be developed.

There are two contrasting viewpoints regarding nationality-based (non-) discrimination by EU competition regulators, though both need more empirical evidence and further theoretical elaboration. On the one hand, some commentators suspect that industrial policy considerations are the main driving force of EU competition policy, and that those companies from third states directly competing with their European ri- 
Strategic or Stringent? Understanding the Nationality Blindness of EU Competition Policy from the Regulatory State Perspective (Yoshizawa)

vals in the same market may be discriminated by the EU. For example, according to this viewpoint, the EU's initial opposition to the merger plan of two American aircraft manufacturers, Boeing and McDonnell Douglas, notified in 1996 was essentially a protection of the largest European aerospace company, Airbus, though in the end the EU gave a conditional permission to them due to US political pressures.

On the other hand, others attribute the cause of such occasional disagreements between the $\mathrm{EU}$ and third states to divergent traditions in competition law and economics across jurisdictions. Furthermore, the EU consistently denies any nationality-based discrimination of firms under EU competition law. For example, in an interview in 2009 featured in Europa, an official journal of the EU Delegation to Japan, then-European Commissioner for Competition Neelie Kroes insisted the impartiality of EU competition policy, especially in terms of the nationality of firms, while pointing out the fact that the company which was imposed the highest cartel penalty fees ever as of 2008 (and remains the record as of January 2015) was a European one: a French company operating in the glass industry, Saint-Gobain. Likewise, third countries such as the US and Japan seem to share this European viewpoint, although their opinions of EU competition policy are generally critical. In a seminal report of 2010 on the implementation of competition law in major trading partners, the Japanese Ministry of Economy, Trade and Industry analyzed EU cartel control during the period of 2003-09. Based on its original statistical analysis, the report concluded that the EU did not target certain companies based on their nationalities during the period examined. As for the US, in the wake of transatlantic tensions due to the EU's controversial blockage of the GE/Honeywell merger plan, both then-Chairman of the Federal Trade Commission Timothy J. Morris and then-Assistant Attorney General of Justice Department, Antitrust Division, Charles A. James clearly denied the EU's discrimination of American and other non-EU based companies as far as merger control was 
『日本 $\mathrm{EU}$ 学会年報』第35号, 平成 27 年 4 月

17)

concerned. In short, both EU and major non-EU competition regulators agree that EU competition policy is essentially nationality-blind.

While further empirical research is necessary to ascertain which of the two arguments is more accurate, the main purpose of this article is rather to develop a heuristic conceptual device so as to directly address this increasingly salient (non-) discrimination issue. The most relevant literature in this respect is the one on the incipient model of strategic competition policy, recently proposed by W. H. Roth. It is a critical assessment of this relatively new model that the next section turns to.

\section{Strategic competition policy: a neomercantilist perspective}

The development of EU competition policy in the last few decades has sharpened the recognition of a dilemma of supranational competition policies such as the EU's one. On the one hand, supranational competition regulation plays an essential role in market integration in that in principle it prohibits anti-competitive business practices across borders which might function as de facto non-tariff barriers to international economic activities (a competition-oriented argument). On the other hand, when its level of regulation is substantially higher than that of major trading partners, supranational competition regulation could negatively affect the international competitiveness of firms within the region while effectively constraining national industrial policies (a competitiveness-oriented argument). In particular, there is a wide belief in Europe that the relatively developed EU state aid control could be a serious disadvantage for European companies because the EU's major trading partners have no comparable rules. Accordingly, a major challenge for the $\mathrm{EU}$ is to strike balance between the two distinctive policy ends, namely the promotion of market competition and the enhancement of the international competitiveness of European firms. 
Strategic or Stringent? Understanding the Nationality Blindness of EU Competition Policy from the Regulatory State Perspective

(Yoshizawa)

\subsection{Defining strategic competition policy}

Since the term 'strategic' means very different things in different contexts, it is necessary to begin with a definition. In this article, competition policy is thought of as strategic when it is instrumentally used for industrial policy goals. In accordance with this understanding, W. H. 19) Roth defines strategic competition policy as 'a policy that goes beyond merely shaping a favorable environment for competition by fostering an attractive infrastructure (in all its dimensions) and sustaining innovation and technological innovation, and conceives and uses competition law as an instrument to assist European competitors on world markets' (emphasis added). Put differently, from the strategic competition policy perspective, the promotion of international competitiveness is the overarching goal of competition policy regardless of whether they are codified in law. It should be noted that this is an essentially neomercantilist reading of competition policy. While the original idea of mercantilism prescribes the pursuit of international trade surplus for greater military spending and prioritizes industry over agriculture, neomercantilism primarily concerns state-driven economic development. Specifically, the latter aims to enhance the international competitiveness of 'national champions' in selected sectors for the maximization of national economic welfare. Thus, according to this line, states are likely to use competition policy as an instrument for the assistance of domestic firms operating internationally.

A distinction between national and supranational (in this case, European) neomercantilism is analytically important here. In contrast to national neomercantilism, which focuses on the creation of national champions with national policies, supranational neomercantilism has two distinctive features, according to the literature: regarding policy goals, it aims to foster European champions, which possess the capacity to compete in the European single market, and eventually in the global market; regarding policy modes, supranational institutions possess far-reaching discretionary power so that they are able to apply competition rules 
in a flexible way for utility maximization. A question is, then, whether the EU actually assists European companies even at the expense of the goal of competition promotion.

\subsection{Empirical and theoretical basis}

Empirically speaking, what has inspired the model of strategic competition policy is the incremental development of industrial policy at the EU level. Since the early 2000s, the EU has developed its holistic industrial policy using the method of policy packaging, while placing greater emphasis on international competitiveness. On the one hand, the Lisbon Strategy of 2000, and its renewed version entitled Europe 2020 launched in 2010, aim to enhance the horizontal and vertical coordination of the union's socioeconomic policies for sustainable, inclusive and knowledgebased economic growth. On the other hand, they seek to improve the EU's capacity as an economic and regulatory actor in the global economy. It follows that if this industrial policy of the $\mathrm{EU}$ is to go beyond a mere stepping stone to economic globalization and strengthen the EU's actorness as a regional entity, that would require greater coherence across policies, both internally and externally. Accordingly, G. Bruzonne and L. Prosperetti maintain that the quest for integration of policies entails the risk that industrial policy objectives will systematically prevail over the objective of maintaining an open market economy based on undistorted competition'. In fact, the European Commission explicitly and extensively refers to the said policy packages in its annual reports on competition policy. While the reports pay little attention to the social policy dimension of the Lisbon Strategy and Europe 2020, they consistently emphasize the potential contributions of market competition to the greater international competitiveness of the European economy.

Theoretically speaking, this model implicitly rests on rational choice institutionalism, which assumes prefixed and narrowly defined (in this case, material) preferences of rational actors. Rational institutionalists un- 
Strategic or Stringent? Understanding the Nationality Blindness of EU Competition Policy from the Regulatory State Perspective (Yoshizawa)

derstand regional integration (e.g. European integration) in a functional way. For example, R. Gilpin asserts that regional economic integration is an instrument of states to increase their bargaining leverage vis-à-vis third states through collective action, and to enhance the international competitiveness of their companies, taking advantage of the scale of the economy. From this viewpoint, the functional substitution of national industrial measures with supranational ones occurs as a conscious decision of states based on cost-benefit calculation.

The existing literature identifies several policy instruments which would serve for the goal of strategic competition policy. (1) Applying the economic theory of strategic trade to competition policy, some people point out the possibility that the relaxation of competition law, typically in the form of exemptions for politically and economically important industries ('target industries'), may be utilized as a de facto subsidy. States may favor less rigorous state aid control, especially in times of economic crisis, because that would give more space to national industrial policies and indirectly support declining firms or sectors. (2) Another possibility is that competition regulators target foreign companies (e.g. arbitrary extraterritorial use of competition law), while applying competition rules to domestic firms less rigorously. (3) Competition regulators may even utilize protectionist measures such as the hindrance of acquisitions of domestic firms by their foreign competitors, though such a practice may trigger retaliatory measures by the countries negatively affected.

\section{Stringent competition policy: a regulatory state perspective}

Although the neomercantilist reading of EU competition policy is not without basis, it seems to have both theoretical and empirical problems when closely examined. Thus, after identifying the problems, this section proposes an alternative model that is stringent competition policy. The 
term 'stringent' highlights two elements at the same time: (1) the strictness of regulation, and (2) the narrowness of what is allowed to do. This model significantly differs from the strategic one in terms of policy styles and objectives among others.

\subsection{Problems with the model of strategic competition policy}

From a theoretical point of view, the model of strategic competition policy makes an analogy between national and supranational competition policies, but does not adequately consider how the EU's supranational institutional setting affects its competition policy. Nor does the model take into account the EU's distinctive market integration objective behind this policy.

From an empirical point of view, as far as individual cases are concerned, EU competition regulators $\underset{33}{\text { are }}$ resistant to member states' political pressures to a considerable degree, and this observation casts doubt on the interpretation of the $\mathrm{EU}$ as a mere agent of the member states. The well-known case of the Schneider/Legrand merger illustrates this point. When a French electrical equipment manufacturer Schneider notified a 7.2 billion euro acquisition of its major domestic competitor Legrand in 2001, the European Commission exerted its power to block this deal suspecting that it would significantly lessen market competition in this sector. Then-French President Jacques Chirac reportedly lobbied then-European Commission President Romano Prodi in the hope of creating a national champion in this ${ }_{35}$ ) political pressure proved unsuccessful. While the prohibition decision was overturned by the General Court later primarily ${ }_{37}$ ) with the European Commission's economic analysis, this case indicates the Commission's considerable autonomy, even in the face of high political pressures from such large member states as France. Since the EU blocked the above-mentioned GE/Honeywell merger plan only a few months before the decision on the Schneider/Legrand case, it was politi- 
Strategic or Stringent? Understanding the Nationality Blindness of EU Competition Policy from the Regulatory State Perspective (Yoshizawa)

cally important that the Commission showed a tough stance against European companies as well as non-European ones.

The relative autonomy of the supranational authorities in regulatory policies illustrated in the Scheneider/Legrand case is a theme that is central to the theory of the regulatory state. Thus, the next section examines main features of this theory and its implications for the issue of (non-) discrimination, while generating a hypothesis.

\subsection{External neutrality of the regulatory state}

The theory of the regulatory state, primarily developed by G. Majone, is useful to explain two interlinked issues, namely the regulatory mode of EU competition policy, and its external neutrality in terms of the nationality of firms. Regarding policy modes, this theory provides a compelling explanation of the EU's exceptionally supranational institutional setting in this policy domain. According to the literature, independent regulatory agencies are pervasive in regulatory policies such as competition policy because they are at arm's length from regulated actors and therefore in $\underset{38}{\text { a }}$ privileged position to assure efficient and non-discriminatory regulation. It follows that non-majoritarian supranational institutions such as the European Commission typify independent regulatory agencies relatively independent from particularistic national and sectoral interests, and are less likely to be captured by special interests than national authorities.

How does such supranational institutional setting affect the external action of the regulatory state? According to the literature, because of the institutionally guaranteed distance from parliamentary control and partisan politics, the legitimacy of non-elected bodies such as the EU competition watchdogs heavily relies on their neutrality concerning the nationality of the regulated (the image as a 'fair referee') rather than input legitimacy. The article develops this argument and maintains that once non-discrimination among European companies is assured, non-EU 
companies would also benefit from it. Otherwise, the credibility of the regulators - in this case, the European Commission and its DirectorateGeneral for Competition - would be seriously undermined. Thus, one may hypothesize that: the supranational institutional setting of the EU in competition policy assures nationality-blind regulation even when nonEU based firms operating within and outside the European internal market are concerned.

This hypothesis should not be confused with an idealistic idea that EU competition policy is purely technical and interest-free or value-free. On the contrary, the EU clearly has its own interests and ideas in this policy field, and they are often explicitly manifested, particularly in external relations. For example, the EU's economic interest comes to the fore where competition and trade policies interact. The European Commission's Global Europe communication of 2006, which sets out a grand strategy of contemporary EU trade policy, asserts that 'rejection of protectionism at home must be accompanied by activism in creating open markets and fair conditions for trade abroad', and that the EU should internationally promote competition law, including state aid control through trade-plus international agreements. Nevertheless, such external activism based on rule exportation does not necessarily contradict with the non-discrimination of third-country firms articulated in the hypothesis.

The essentially nationality-blind nature of EU competition policy hypothesized above is theoretically consistent with the EU's distinct conception of competition and competitiveness. In this light, sociological institutionalism supplements the theory of the regulatory state by explicitly highlighting the role of ideas embedded in institutions. A key idea here is the EU's understanding of competition policy as a functional complement to the operation of the internal market. This market integration ethos has been a key in EU competition policy, even after the completion of the single market, and it is reflected in the EU's under- 
Strategic or Stringent? Understanding the Nationality Blindness of EU Competition Policy from the Regulatory State Perspective (Yoshizawa)

standing of international 'competitiveness', as will be explained below. In this sense, as sociological institutionalists argue, the internal experience of the EU significantly constrains and shapes its external policy.

Specifically, the article makes a twofold argument. First, when closely examined, the idea of international competitiveness stressed in the Lisbon Strategy and the Europe 2020 program is vaguely defined and does not necessarily focus on the competitiveness of individual firms and the creation of national/European champions. Rather, in the context of competition policy, the EU puts stress on the maintenance of the competitive market environment (level-playing field) of the EU economy as a whole. For example, the European Commission's annual report on competition policy 2010 states that competition policy has great potential to contribute to the goals of Europe 2020 because:

'[Competition policy] is a key driver for making markets work better through an efficient allocation of resources and increased productivity and innovation. It therefore underpins the competitiveness of the EU economy, which is more important than ever to maintain economic and financial stability' (emphasis added).

Second, reflecting its core identity as a single market based on the logic of negative integration, the EU largely disassociates competitiveness and the nationality of companies. Thus, the greater emphasis on international competitiveness in EU discourse does not necessarily result in the practice of discrimination of non-EU companies as the model of strategic competition policy anticipates. This point is evident in the following statement made by former European Commissioner for Competition Joaquín Almunia in 2011 with special reference to merger control:

'Foreign takeovers do not threaten competitiveness nor do they threaten growth and jobs. They are a fact of life in the global economy, and it is a fact that European firms invest in joint ventures abroad. So I do not agree with those that would want to reduce vital investment flows into the European Union. In effect, 
『日本 $\mathrm{EU}$ 学会年報』第35号, 平成 27 年 4 月

Table: A comparison of the main and rival models Stringent competition policy Strategic competition policy (Main model) (Rival model)

\begin{tabular}{|c|c|c|}
\hline \multirow[t]{3}{*}{ Policy style } & Strict law enforcement & Administrative discretion \\
\hline & $\begin{array}{l}\text { Resilience in the face of economic } \\
\text { crises }\end{array}$ & $\begin{array}{l}\text { Sensitivity to socioeconomic con } \\
\text { ditions }\end{array}$ \\
\hline & $\begin{array}{l}\text { Non-discrimination regarding the } \\
\text { nationality of firms }\end{array}$ & $\begin{array}{l}\text { Tendency to foster and protect } \\
\text { European champions }\end{array}$ \\
\hline Policy objectives & $\begin{array}{l}\text { Correction of market failures; } \\
\text { maintenance of a level-playing } \\
\text { field }\end{array}$ & $\begin{array}{l}\text { Promotion of indigenous compa- } \\
\text { nies' international competitiveness }\end{array}$ \\
\hline Scope of exemptions & Minimum & Wide coverage \\
\hline $\begin{array}{l}\text { Primary role of the } \\
\text { regulator }\end{array}$ & Guardian of market competition & Promoter of economic welfare \\
\hline $\begin{array}{l}\text { Underlying theories } \\
\text { of institutions }\end{array}$ & $\begin{array}{l}\text { Sociological institutionalism (insti- } \\
\text { tutions embedding norms as well } \\
\text { as interests) }\end{array}$ & $\begin{array}{l}\text { Rational choice institutionalism } \\
\text { (institutions as the instrument of } \\
\text { rational actors) }\end{array}$ \\
\hline
\end{tabular}

Source: The main model is developed from Majone (1996: 68-72), especially in respect to the policy goals and the role of independent agencies, whereas the rival model largely draws on Roth (2006: 38-39) and Jacquemin (1993: 95-96).

when we examine mergers and acquisitions, we do so regardless of where the capital or business comes from.'

In short, the EU sees competition policy through the lens of the internal market, and such idea embedded in the supranational institutional design assures the nationality blindness of EU competition regulation.

\subsection{Differences and similarities between the two models}

A comparison of the strategic and stringent readings of EU competition policy helps to understand their features (see the table above). As explained above, the stringent competition policy perspective assumes strict law enforcement and narrowly defined areas of exemptions, underpinned by the relative autonomy of the regulator. On the one hand, the supranational institutional setting assures nationality-blind regulation. On the other hand, it allows competition regulators to stick to competition policy criteria in the decision making process, though the relative 
Strategic or Stringent? Understanding the Nationality Blindness

of EU Competition Policy from the Regulatory State Perspective (Yoshizawa)

weight of non-competition criteria also depends on minimalist or maximalist trends in public regulation depending on prevailing politics. The main goal of this policy is the promotion of market competition through the correction of market failures such as a monopoly. By contrast, the strategic one is characterized by such features as flexible law enforcement depending on socioeconomic situations; a wide coverage of exemptions, particularly in target sectors; and the objective of promoting European champions. From this perspective, the supranational institutional setting results from the member states' utility-maximizing strategy rather than commitment to non-discriminatory policy enforcement.

There is one point in common between the two models: they both take a position that economic globalization does not necessarily result in the marginalization of governments. This is in line with the extensive literature on EU public policies, which highlights the sustained relevance of public regulation in Europe as well as North America even after the rise of neoliberalism in the 1980s and 1990s. Nonetheless, one can hardly overemphasize the fundamental differences between the two models in terms of policy styles, objectives, and theoretical underpinnings.

\section{Conclusion}

This article has made an initial step towards the analysis of a particular external aspect of EU competition policy that is the nationalitybased (non-) discrimination of non-EU companies. Overall, the article has argued that the best way to understand this issue is to bring it into dialogue with the competition and/versus competitiveness debate in the study of international political economy. Specifically, this study has made a heuristic distinction between strategic and stringent competition policies, which rest on two different and potentially irreconcilable conceptions of competition and competitiveness.

From a theoretical point of view, the main contribution of the article 
is its original model of stringent competition policy, and it has been developed drawing on two theories. On the one hand, the article has demonstrated that the theory of the regulatory state helps to understand the supranational institutional setting of EU regulatory policies such as competition policy, while explaining the non-discriminatory nature of EU competition regulation in terms of the nationality of firms. On the other hand, sociological institutionalism is useful to make sense of the EU's distinctive approach to external competition regulation, which is fundamentally affected by its internal experience of the establishment of the internal market. This model overcomes the limitations of the strategic competition policy model, but it does not mean that the latter is completely invalidated. The two competing models should be subjected to further empirical inquiry.

From a methodological point of view, the article has a merit in that it has used multiple sources, both EU and non-EU, in order to sufficiently address the issue of (non-) discrimination in EU competition policy. This approach may sound straightforward and even obvious, but in reality, few researchers fully appreciate its importance. Thus, it is worth stating that any future research on this subject should pay close attention to sources from outside the EU. Put differently, it is more important than ever to critically assess EU competition policy with 'foreign eyes', not because those foreign eyes are always correct, but because this policy has a considerable economic and legal impact well beyond the geographical reach of the union.

Future research may tackle the question of whether EU competition policy is becoming more strategic or stringent, especially in the last fifteen years wherein both competition policy and industrial policy of the EU have made major developments. One major factor that the article could not address because of restricted word limits is the way in which systemic level constraints inform and shape EU competition policy. It might be a case that strategic competition policy is generally becoming 
Strategic or Stringent? Understanding the Nationality Blindness

of EU Competition Policy from the Regulatory State Perspective (Yoshizawa)

less acceptable in Europe and other regions because of the development of international standards promoted by institutions such as the International Competition Network and the Organization for Economic Cooperation and Development. This global environment surrounding the EU deserves further research. In spite of these reservations, the article has made a positive contribution to the literature by shedding light on the important and yet understudied aspect of EU competition policy.

* Drafts of this article were presented at the GEM Workshop 'External EU Governance in Competition Policy' in Brussels on 20 January 2014, the 'European European Union in International Affairs IV' Conference in Brussels on 24 May 2014, and the EUSA-Japan Annual Conference in Tokyo on 9 November 2014. The author is very thankful to the two anonymous reviewers and all who provided feedback on this work, especially Prof. Amandine Crespy, Dr. Angela Wigger, Dr. Davor Jancic, Prof. Koji Fukuda, Prof. Tokuhiko Obata and Ms. Lisa Tilley. This study is largely based on ongoing $\mathrm{PhD}$ research conducted by the author as a doctoral fellow at Erasmus Mundus Joint Doctorate: Globalization, European Union and Multilateralism (GEM PhD School) financially supported by the European Commission.

1) For the relative strength of the EU's power in those areas, see Damro, Chad (2012) 'Market power Europe', Journal of European Public Policy, Vol. 19, No. 5, pp. 682-699; Telò, Mario (2009) 'Introduction', in Mario Telò (ed.) The European Union and Global Governance, New York: Routledge, pp. 1-39.

2 ) There is a substantial number of works which demonstrate the exceptionally supranational institutional setting of EU competition policy. See, for example, Cini, Michelle, and McGowan, Lee (2009) Competition Policy in the European Union, 2nd edition, Basingstoke: Palgrave Macmillan; McGowan, Lee, and Wilks, Stephen (1995) 'The first supranational policy in the European Union: Competition Policy', European Journal of Political Research, Vol. 28, No.2, pp. 141-169.

3 ) All of the following studies demonstrate the impact of EU competition law on member states' competition laws, while showing its limits, especially in the case of those member states with dirigiste traditions. Wada, Satoko (2011) The Competition Policies of the EU and France (EU とフランスの競争政策), Tokyo: NTT Shuppan; McCann, Dermot (2010) The Political Economy of the European Union: An Institutionalist Per- 
『日本 $\mathrm{EU}$ 学会年報』第 35 号, 平成 27 年 4 月

spective, Cambridge: Polity, Chapter 3; Cases, Lluis (1996) 'Competition law and policy in Spain: implementation in an interventionist tradition', in Giandomenico Majone (ed.) Regulating Europe, New York: Routledge, pp. 180-201.

4) The following two articles stress the persistent dominance of supranational institutions in the decision-making process in EU competition policy, while analyzing the evolving roles of national competition regulators. Suami, Takao (2012) 'Constitutional Consideration of EU Competition Law: Constitutional Pluralism and the Modernization of EU Competition Law' (EU 競争法の憲法的考察一憲法的多元主義と EU 競争法の現代化 -), EU Studies in Japan, Vol. 32, pp.65-91; Wilks, Stephen (2005) 'Agency escape: decentralization or dominance of the European Commission in the modernization of competition policy?', Governance, Vol. 18, No. 3, pp. 431-452.

$5)$ Papadopoulos, Anestis S. (2010) The International Dimension of EU Competition Law and Policy, Cambridge: Cambridge University Press.

6) Gerber, David J. (2010) Global Competition: Law, Markets and Globalization, Oxford: Oxford University Press.

7) Dabbah, Maher M. (2003) The Internationalization of Antitrust Policy, New York: Cambridge University Press.

8) Aoyagi, Yuka (2012) 'External Regulatory Power of EU Competition Law' (EU 競争 法の対外的な規制力), in Ken Endo and Kazuto Suzuki (eds.) The Regulatory Power of the EU (EU の規制力), Tokyo: Nihon Keizai Hyoronsha, pp. 111-128.

9) Aydin, Umut (2012) 'Promoting Competition: European Union and the Global Competition Order, Journal of European Integration, Vol. 34, No.6, pp. 663-681.

10) Dewatripont, Mathias, and Legros, Patrick (2009) 'EU competition policy in a global market', in Mario Telò (ed.) The European Union and Global Governance, New York: Routledge, p. 92.

11) Case No IV/M. 877, Boeing/McDonnell Douglas, Commission decision of 30 July 1997, OJ L336/16, 8 December 1997. For a detailed analysis of transatlantic politics behind this case and its implications for the EU's external competition policy, see Damro, Chad (2001) 'Building an international identity: the EU and extraterritorial competition policy', Journal of European Public Policy, Vol. 8, No. 2, pp. 208-226.

12) Fox, Eleanor (1998) 'Antitrust Regulation Across National Borders: The United States of Boeing Versus the European Union of Airbus', Brookings Review, available at http://www.brookings.edu/research/articles/1998/12/winter-business-fox, accessed 20 October 2014 .

13) EU Delegation to Japan (2009) 'Competition policy which brings about consumer welfare’ (消費者に利益もたらす競争政策), Europa, Vol. 257, p. 7. This paper-based magazine of the EU Delegation to Japan was replaced by an online magazine, EU MAG, in 2012 . 
Strategic or Stringent? Understanding the Nationality Blindness

of EU Competition Policy from the Regulatory State Perspective (Yoshizawa)

14) Case No COMP/39.125, Car glass, Summary of Commission decision of 12 November 2008, OJ C173/13, 25 July 2009. Saint-Gobain reportedly engaged in an international car glass cartel and was imposed a penalty of 880 million euros by the European Commission.

15) Japanese Ministry of Economy, Trade and Industry (2010) Report by a Study Group regarding Competition Law Compliance-Anti-cartel Measures by Japanese Corporations and Trade Associations in Light of Enhanced Global Enforcement of Competition Law (競争法コンプライアンス体制に関する研究会報告書一国際的な競争法執行強化を踏まえた企 業・事業者団体のカルテルに倸る対応策一).

16) Case No COMP/M. 2220, General Electric/Honeywell, Commission decision of 3 July 2001, OJ L48/1, 18 February 2004. Both GE and Honeywell are American companies, and this prohibition decision therefore exemplifies the extraterritorial application of $\mathrm{EU}$ competition law. For an in-depth legal and political analysis of this case, see Morgan, Eleanor J., and McGuire, Steven (2004) 'Transatlantic divergence: GE-Honeywell and the EU's merger policy', Journal of European Public Policy, Vol. 11, No. 1, pp. 39-56

17) Muris, Timothy J. (2001) 'Merger Enforcement in a World of Multiple Arbiters', paper presented at Brookings Institution Roundtable on Trade and Investment Policy, Washington DC, 21 December 2001, available at 〈http://www.ftc.gov/speeches/muris/ brookings.pdf $\rangle$, accessed 20 October 2014; James, Charles A. (2001) 'Reconciling divergent enforcement policies: Where do we go from here?', speech at the 28th Annual Conference on International Law and Policy, Fordham Corporate Law Institute, New York, 25 October 2001, available at http://www.justice.gov/atr/public/speeches/9395.htm, accessed 20 October 2014 .

18) Blauberger, Michael, and Kramer, Rike U. (2010) 'European Competition v. s. Global Competitiveness: Transferring EU Rules on State Aids and Public Procurement Beyond Europe', CCP Working Paper, 10-10, pp. 5-7; Dewatripont and Legros, op. cit., p. 89.

19) Roth, Wulf-Henning (2006) 'Strategic competition policy: a comment on EU competition policy', in Hanns Ullrich (ed.) The Evolution of European Competition Law: Whose Regulation, Which Competition ?, Cheltenham: Edward Elgar, p. 39.

20) Gilpin, Robert (2001) Global Political Economy: Understanding the International Economic Order, Princeton: Princeton University Press, p. 157.

21) For the distinction between national and supranational neomercantilism, see BuchHansen, Hubert, and Wigger, Angela (2011) The Politics of European Competition Regulation: a critical political economy perspective, New York: Routledge, pp. 22-23. It should be noted that Buch-Hansen and Wigger neither propose nor support the model of strategic competition policy. For their theoretical approach, see Section 3.3.

22) Rodrigues, Maria J. (2009) Europe, globalization and the Lisbon Agenda: an intro- 
『日本 $\mathrm{EU}$ 学会年報』第35号, 平成 27 年 4 月

duction', in Maria J. Rodrigues (ed.) Europe, Globalization and the Lisbon Agenda, Cheltenham: Edward Elgar, pp. 1-19.

23) European Commission (2010) Europe 2020: A strategy for smart, sustainable and inclusive growth, COM (2010) 2020, 3 March 2010.

24) Telò, Mario (2009) 'The Lisbon Strategy as a global EU strategy', in Rodrigues, op. cit., pp. 234-245.

25) But see also the following, which regards regional economic agreements as inherently impediment to global economic liberalization: Bhagwati, Jagdish (1993) 'Regionalism and Multilateralism, an overview', in Jaime De Melo and Arvind Panagariya (eds.) New Dimensions in Regional Integration, London: Cambridge University Press, pp. 2251.

26) Telò, op. cit.

27) Bruzzone, Ginevra, and Prosperetti, Luigi (2009) 'Market Integration and Competition Policy: The Challenges Ahead', in Stefano Micossi and Gian L. Tosato (eds.) The European Union in the 21st Century: Perspectives from the Lisbon Treaty, Brussels: Centre for European Policy Studies, pp. 74-99, pp. 82-83.

28) Gilpin, op. cit., p. 361.

29) Ibid., pp. 357-358.

30) For a critical assessment of this theory, see Krugman, Paul (ed.) (1986) Strategic Trade Policy and the New International Economics, Cambridge: MIT Press.

31) Swan, Dennis (1983) Competition and Industrial Policy in the European Community, London; New York: Methuen.

32) Jacquemin, Alexis (1993) 'The International Dimension of European Competition Policy', Journal of Common Market Studies, Vol. 31, No. 1, pp.91-101.

33) Levy, Nicholas (2005) 'Mario Monti's Legacy in EC Merger Control', Competition Policy International, Vol. 1, No. 1, p. 131.

34) Case No COMP/M. 2283, Schneider/Legrand, Commission decision of 30 January 2002, OJ L101/134, 6 April 2004.

35) The Economist (2001) 'Schneider/Legrand: A shocking denouement: Why it does not pay to second-guess Europe's antitrust regulators', 11 October 2001, available at http://www.economist.com/node/814366, accessed 20 October 2014.

36) It was known as the Court of First Instance at that time.

37) Case T-310/01, Schneider Electric v Commission, ECLI: EU: T: 2002: 254 (22 October 2002).

38) Thatcher, Mark (2011) 'The creation of European regulatory agencies and its limits: a comparative analysis of European delegation', Journal of European Public Policy, Vol. 18, No. 6, pp. 790-809.

39) Majone, Giandomenico (1996) 'The European Commission as regulator', in Giando- 
Strategic or Stringent? Understanding the Nationality Blindness

of EU Competition Policy from the Regulatory State Perspective (Yoshizawa)

menico Majone (ed.) Regulating Europe, London: Routledge, pp. 71.

40) Ibid.

41) European Commission (2006) Global Europe: Competing in the World: A Contribution to the EU's Growth and Jobs Strategy, COM (2006) 567 Final, 4 October 2006, pp. 5-7. The quotation is from page 5 .

42) For sociological institutionalism, see, for example, Hall, Peter, and Taylor, Rosemary C. R. (1996) 'Political science and the three new institutionalisms', Political Studies, Vol. 44, No. 5, pp. 952-973, especially pp. 946-950.

43) Korah, Valentine (2007) An Introductory Guide to EC Competition Law and Practice, Portland, OR: Hart Publishing, pp. 13-14. See also the following landmark judgment of the Court of Justice: Joined cases 56 \& 58-64, Établissements Consten S. $a$. $R$. L. and Grundig-Verkaufs-GmbH $v$ Commission of the European Economic Community, ECLI: EU: C: 1966: 41 (13 July 1966).

44) Elgström, Ole, and Smith, Michael (1996) 'Introduction', in Ole Elgström and Michael Smith (eds.) The European Union's Roles in International Politics, London: Routledge, pp. 1-10.

45) European Commission (2011) Report on Competition Policy 2010, COM (2011) 328 final, 10 June 2011, p. 11.

46) Damro, op. cit.

47) Almunia, Joaquín (2011) 'Improving Europe's competitiveness in the global economy', SPEECH/11/481, available at http://europa.eu/rapid/press-release_SPEECH-11-481_ en.htm?locale $=$ en, accessed 20 October 2014 .

48) For the impact of macro-economic situations on EU competition policy from a critical political economy perspective, see Buch-Hansen and Wigger, op. cit.

49) See the following for the well-known paradox of reregulation after deregulation: Majone, Giandomenico (1994) 'The Rise of the Regulatory State in Europe', West European Politics, Vol. 17, No. 3, pp.77-101. See also the following for more recent debates on regulatory capitalism: Levi-Faur, David (2005) 'The Global Diffusion of Regulatory Capitalism', The ANNALS of the American Academy of Political and Social Science, Vol. 598, pp. $12-32$.

50) The author is thankful to Prof. Tokuhiko Obata (University of Marketing and Distribution Sciences) for mentioning this point at the EUSA-Japan Annual Conference in Tokyo on 9 November 2014. 